\title{
Study of Serum Level of IL10, CD4, CD8 and Acute Phase Reactants in Thalassemic Children with Effect of Splenectomy
}

\author{
MARWA M.A. KHATTAB, M.Sc.*; SHEBL S. SHEBL, M.D.*; IBRAHIM M. BADRAIA, M.D.*; \\ MAALY M. MABROUK, M.D.** and YASMINE SH. SAID, M.D.* \\ The Departments of Pediatrics* and Clinical Pathology**, Faculty of Medicine, Tanta University, Tanta, Egypt
}

\begin{abstract}
Background: Thalassemia is one of the most common single gene disorders and widely distributed in the Mediterranean region and inherited as autosomal recessive disorders. Beta-thalassemia major has an increased risk for systemic infections, suggesting that a basic defect in the host defense is present.
\end{abstract}

Aim of Study: It was to study the level of (interleukin 10, CD4, CD8 subsets) in thalassemic patients and correlation with certain acute phase reactants and as well as effect of splenectomy.

Patients and Methods: The study was carried out on 40 children with thalassemia who attended to Hematology Unit, Pediatrics Department, Tanta University Hospital at the period from June 2016 to February 2017. Also it included 20 healthy children with matched age and sex served as a control group All patients and controls were subjected to full history taking, clinical examination, routine laboratory investigations, CD4, $\mathrm{CD} 8, \mathrm{CD} 4 / \mathrm{CD} 8$ ratio and interleukin 10 measurements.

Results: This study found that CD4 and CD8 are significantly higher in post splenectomised thalassemic patients compared with non splenectomised thalassemic patients and control group ( $p$-value $>0.05)$. While interleukin 10 was significantly lower in post splenectomised thalassemic patients compared with non splenectomised thalassemic patients and control group ( $p$-value $>0.05$ )

Conclusion: There are significant differences in immune responses among post-splenectomy and non-splenectomy thalassemic patients. There were significant higher level of CD4, CD8 and lower IL10 in the splenectomised thalassemic patients than non splenectomised thalassemic patients and controls. There were significant negative correlation between CD4/CD8 ratio and interleukin 10 (IL10). While there were no significant correlation between CD4, CD8 and interleukin 10 (IL10). There was statistically significant correlation between CD4, CD8 and serum ferritin.

Correspondence to: Dr. Marwa M.A. Khattab, The Department of Pediatrics, Faculty of Medicine, Tanta University, Tanta, Egypt
Key Words: Thalassemia - Immune response - Splenectomy.

\section{Introduction}

THALASSEMIA is recognized as the most prevalent hereditary disorder all over the world with a significant negative impact on public health and the society especially endemic areas [1]. The most prevalent hemoglobinopathy in Egypt is B-thalassemia major which is a hereditary genetic anemia of hemolytic type. It is considered in our region a problematic health issue [2] .

Thalassemia is prevalent in Mediterranean countries, the Middle East, central Asia, India, Southern China and the Far East as well as countries along the north coast of Africa and in South America. The highest carrier frequency is reported in Cyprus (14\%), Sardinia (10, 3\%) and South East Asia [3]

Infections are frequent complication of thalassemia (12-13\%) and hemoglobinopathies and they can be fatal. Beta-thalassemia major has an increased risk for systemic infections, suggesting that a basic defect in the host defense is present [4].

Furthermore, a research on cellular immunity on thalassemia patients showed increase amount and activity of suppressor cell $\mathrm{CD} 8+$, decrease ratio of $\mathrm{CD} 4+/ \mathrm{CD} 8+$, decrease of $\mathrm{T}$ lymphocyte proliferation and increase $\mathrm{T}$ lymphocyte activation whereas humoral immunity research showed similar result between thalassemia and normal person [5]

Interleukin-10 (IL-10) is a key immunosuppressive cytokine that is produced by a wide range of leukocytes, as well as non -hematopoietic cells [6] 
IL-10 influences three important functions of the monocytes/macrophages: The release of immune mediators, the antigen presentation, and the phagocytosis [7].

The exact molecular mechanisms of immunosuppressive effects of IL-10 on APCs (the inhibition of cytokine production and antigen presentation) and $\mathrm{T}$ cells (the suppression of cytokine production and proliferation) $[8]$.

Aim:

It was to study the level of (interleukin 10, CD4, CD8 subsets) in thalassemic patients and correlation with certain acute phase reactants and as well as effect of splenectomy.

\section{Patients and Methods}

The patients had been randomly selected from Hematology Unit, Pediatric Department, Tanta University Hospital at the period from June 2016 to February 2017.

The study was carried out on the following groups:

Group (I): 20 cases of 3 -thalassemia major who were splenecomized.

Group (II): 20 cases of $\beta$-thalassemia major who were not splenecomized.

Group (III): 20 healthy children serving as a control group.

Exclusion criteria were: Other types of hemolytic anemia as sickle thalassemia, autoimmune hemolytic anemia, sickle cell anemia and G6PD.

Both patients and control groups were subjected to the following: Full history taking, clinical examination and laboratory investigations include: Complete blood count.

- Hb electrophoresis by HPLC.

- Serum ferritin by ELISA.

- ESR \& C-RP.

- CD4, CD8 and CD4/CD8 ratio by flow cytometry.

- Serum level of IL10 by ELISA.

Statistical presentation and analysis of the present study was conducted using the mean, standard deviation, student $t$-test, Chi-square by SPSS V20 with $p<0.05$ means significance [9] .

\section{Results}

This study was carried out at the Pediatric Department of Tanta University Hospital on three groups of children (20 post splenectomised thalassemic patients, 20 non splenectomised thalassemic patients, 20 healthy children who served as control group).

Table (1) presents the demographics data of the case control study population as regard age, sex, family history of similar condition and family history of positive consanguinity. It shows that there are significant difference between thalassemic patients and control group as regard age, family history of similar condition and positive consanguinity ( $p$-value $>0.001$ ). While there are no significant difference between thalassemic patients and control group as regard sex ( $p$-value $=0.760)$.

Table (2) shows significant difference between the studied groups regarding serum ferritin ( $p$ value $>0.05)$. As serum ferritin increase in splenectomised thalassemic patients (group I) than non splenectomised thalassemic patients (group II) and control group.

Table (3) shows significant difference between the studied groups regarding $\mathrm{C}$-reactive protein ( $p$-value >0.05). As C-reactive protein increase in splenectomised thalassemic patients (group I) than non splenectomised thalassemic patients (group II) and control group.

Table (4) shows significant difference between the studied groups regarding ESR ( $p$-value >0.05). As ESR increased in splenectomised thalassemic patients (group I) than non splenectomised thalassemic patients (group II) and control group.

Table (5) shows significant difference between the studied groups regarding CD4 and CD8 ( $p$ value >0.05). As CD4 and CD8 increased in splenectomised thalassemic patients (group I) than non splenectomised thalassemic patients (group II) and control group.

Table (6) shows no significant difference between group (I) and group (II) regarding CD4: $\mathrm{CD} 8$ ratio $(p$-value $>0.05)$. While there was significant difference between group (I) and controls regarding CD4: CD8 ratio ( $p$-value $>0.05$ ).

Table (7) shows significant difference between the studied groups regarding interleukin 10 (IL 10) ( $p$-value >0.05). As interleukin 10 (IL10) decreased in splenectomised thalassemic patients (group I) than non splenectomised thalassemic patients (group II) and control group. 
Table (1): Demographic and laboratory data of the studied groups.

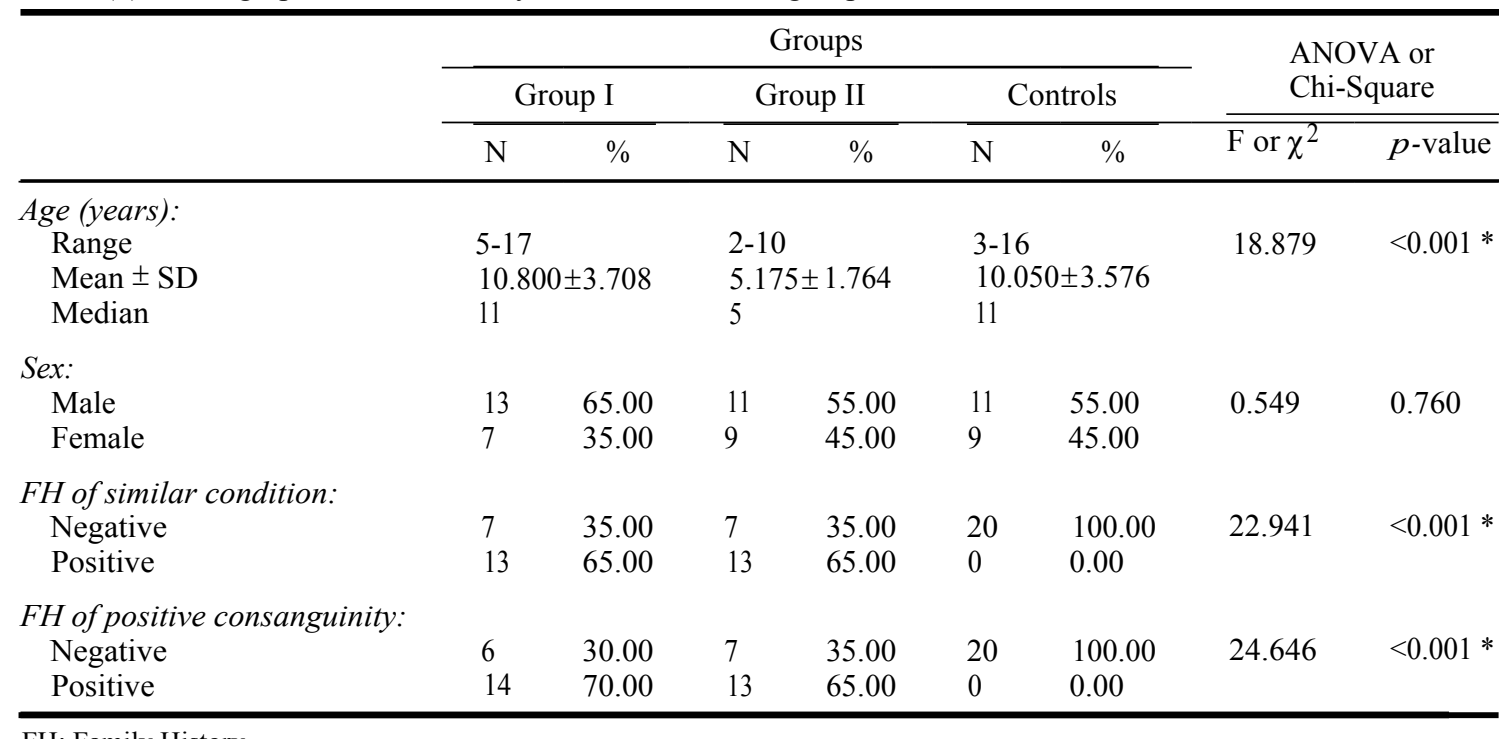

FH: Family History.

Table (2): Comparison between studied groups as regard Serum ferritin.

\begin{tabular}{|c|c|c|c|c|c|}
\hline \multirow{2}{*}{ Groups } & \multicolumn{3}{|c|}{ Serum ferritin $\mathrm{ng} / \mathrm{ml}$} & \multicolumn{2}{|c|}{ ANOVA } \\
\hline & Range & Mean \pm SD & Median & $\mathrm{F}$ & $p$-value \\
\hline Group I & $1853-7581$ & $4886.200 \pm 1400.293$ & 4820 & 109.057 & $<0.001 *$ \\
\hline Group II & $850-5160$ & $2309.050 \pm 1105.624$ & 2130 & & \\
\hline \multirow[t]{4}{*}{ Gontrols } & $35-223$ & $76.950 \pm 58.601$ & 48 & & \\
\hline & \multicolumn{4}{|c|}{ TUKEY'S Test } & \\
\hline & I \& II & I \& III & \multicolumn{2}{|c|}{ II \& III } & \\
\hline & $<0.001 *$ & $<0.001 *$ & \multicolumn{2}{|c|}{$<0.001 *$} & \\
\hline
\end{tabular}

Table (3): Comparison between the studied groups as regard C-Reactive Protein (CRP).

\begin{tabular}{|c|c|c|c|c|c|c|c|c|c|c|}
\hline \multirow{3}{*}{ CRP mg/l } & \multicolumn{8}{|c|}{ Groups } & \multirow{2}{*}{\multicolumn{2}{|c|}{ Chi-Square }} \\
\hline & \multicolumn{2}{|c|}{ Group I } & \multicolumn{2}{|c|}{ Group II } & \multicolumn{2}{|c|}{ Controls } & \multicolumn{2}{|c|}{ Total } & & \\
\hline & $\mathrm{N}$ & $\%$ & $\mathrm{~N}$ & $\%$ & $\mathrm{~N}$ & $\%$ & $\mathrm{~N}$ & $\%$ & $\chi^{2}$ & value \\
\hline Negative & 3 & 15.00 & 10 & 50.00 & 20 & 100.00 & 33 & 55.00 & 29.495 & $<0.001 *$ \\
\hline Positive & 17 & 85.00 & 10 & 50.00 & 0 & 0 & 27 & 45.00 & & \\
\hline Total & 20 & 100.00 & 20 & 100.00 & 20 & 100.00 & 60 & 100.00 & & \\
\hline
\end{tabular}

Table (4): Comparison between the studied groups as regard ESR.

\begin{tabular}{|c|c|c|c|c|c|c|c|c|}
\hline & \multicolumn{3}{|c|}{ Groups } & \multicolumn{2}{|c|}{ ANOVA } & \multicolumn{3}{|c|}{ TUKEY'S Test } \\
\hline & Croup I & Croup II & Controls & $\mathrm{F}$ & $p$-value & I \& II & I \& III & II \& III \\
\hline \multicolumn{9}{|l|}{ ESR 1 st $\mathrm{mm} / \mathrm{h}:$} \\
\hline Range & $15-100$ & $13-60$ & $4-12$ & 56.585 & $<0.001 *$ & $<0.001 *$ & $<0.001 *$ & $<0.001 *$ \\
\hline Mean \pm SD & $57.650 \pm 22.276$ & $26.400 \pm 13.248$ & $7.650 \pm 2.183$ & & & & & \\
\hline Median & 60 & 22 & 8 & & & & & \\
\hline \multicolumn{9}{|l|}{ ESR $2^{\text {nd }} \mathrm{mm} / \mathrm{h}$ : } \\
\hline Range & $20-125$ & $22-92$ & $11-23$ & 52.152 & $<0.001 *$ & $<0.001 *$ & $<0.001 *$ & $<0.001 *$ \\
\hline Mean \pm SD & $79.650 \pm 28.150$ & $42.550 \pm 18.953$ & $16.150 \pm 4.368$ & & & & & \\
\hline Median & 80 & 35 & 17.5 & & & & & \\
\hline
\end{tabular}


Table (5): Comparison between the studied groups as regard CD4 (T lymphocyte) and CD8 (T lymphocyte).

\begin{tabular}{lllllllll}
\hline & \multicolumn{2}{c}{ Groups } & \multicolumn{2}{c}{ ANOVA } & \multicolumn{2}{c}{ TUKEY'S Test } \\
\cline { 2 - 8 } & Croup I & Croup II & Controls & F & $p$-value & I \& II & I \& III & II \& III \\
\hline CD4 cell $/ \mathrm{mm}^{3}:$ & & & & & & & & \\
Range & $1150-7371$ & $423-1898$ & $314-978$ & 36.677 & $<0.001 *$ & $<0.001 *$ & $<0.001 *$ & 0.585 \\
Mean \pm SD & $3617.519 \pm 2099.646$ & $922.500 \pm 416.291$ & $533.400 \pm 181.980$ & & & & & \\
Median & 3039.5 & 942 & 538 & & & & & \\
CD8 cell $/ \mathrm{mm}^{3}:$ & & & & & & & & \\
Range & $760-5650$ & $310-1915$ & $232-820$ & 33.338 & $<0.001 *$ & $<0.001 *$ & $<0.001 *$ & 0.723 \\
Mean \pm SD & $2560.950 \pm 1511.176$ & $658.500 \pm 372.562$ & $438.650 \pm 169.583$ & & & & & \\
Median & 2064 & 630 & 455 & & & & & \\
\hline
\end{tabular}

Table (6): Comparison between the studied groups as regards CD4: CD8 ratio.

\begin{tabular}{|c|c|c|c|c|}
\hline \multirow{2}{*}{ Groups } & \multicolumn{4}{|c|}{ CD4:CD8 Ratio } \\
\hline & Range & & $\pm \mathrm{SD}$ & Median \\
\hline Group I & $1-2.4$ & & \pm 0.375 & 1.6 \\
\hline Group II & $0.6-2.5$ & & \pm 0.477 & 1.4 \\
\hline \multirow[t]{4}{*}{ Gontrols } & $1.02-1.4$ & & \pm 0.121 & 1.2 \\
\hline & \multicolumn{3}{|c|}{ TUKEY'S Test } & \\
\hline & I \& II & I \& III & II \& III & \\
\hline & 0.096 & $<0.001 *$ & 0.077 & \\
\hline
\end{tabular}

Table (7): Comparison between the studied groups as regard interleukin 10 (IL10).

\begin{tabular}{|c|c|c|c|c|c|}
\hline \multirow{2}{*}{ Groups } & \multicolumn{3}{|c|}{ IL10 pg/ml } & \multicolumn{2}{|c|}{ ANOVA } \\
\hline & Range & Mean $\pm \mathrm{SD}$ & Median & $\mathrm{F}$ & $p$-value \\
\hline Group I & $23-616$ & $\begin{array}{l}258.155 \pm \\
197.527\end{array}$ & 295 & 5.090 & $0.009 *$ \\
\hline Group II & $126-4740$ & $\begin{array}{l}1366.500 \pm \\
1565.521\end{array}$ & 387 & & \\
\hline \multirow[t]{4}{*}{ Gontrols } & $13.8-4530$ & $\begin{array}{l}1195.400 \pm \\
1306.415\end{array}$ & 923 & & \\
\hline & \multicolumn{4}{|c|}{ TUKEY'S Test } & \\
\hline & I \& II & I \& III & & \& III & \\
\hline & $0.012 *$ & $0.039^{*}$ & & .891 & \\
\hline
\end{tabular}

\section{Discussion}

The most prevalent type of hereditary anemia in Egypt is B-thalassemia. The carrier incidence rate is more than $10 \%[10]$

There are various causes of infection including blood transfusion, splenectomy, iron overload in the body, and aberration of function in immunity system. Infections are the first or second cause of death (after heart failure) in thalassemia and hepatic disease is the third most common cause of death [11].

In our study, we compared between thalassemic and control groups regarding age, sex, family history of positive consanguinity, and family history of similar condition, clinical examination, and laboratory investigations.

In our study, there was statistically significant difference between thalassemic patients and control group as regard family history of similar condition ( $p$-value $>0.001)$ and family history of positive consanguinity $(p$-value $>0.001)$.

This data come in agreement with Rekha and Machado, [12] who demonstrated that; thalassemia is one of the most common single gene disorders and widely distributed in the mediterranean region and inherited as autosomal recessive disorders.

In our study, there was statistically significant difference between thalassemic patients and control group as regard serum ferritin which was significantly higher in thalassemic patients compared with control group ( $p$-value $>0.05$ ).

This data come in agreement with Martin and Thompson, [13] who demonstrated that; serum ferritin levels in those with thalassemia major may be elevated, reflecting the presence of iron overload primary from repeated blood transfusion, but to lesser extent from increased absorption of dietary iron from the gastrointestinal tract. Also in another study, Eissa and El-Gamal, [14] reported that older patients with thalassemia ( $>12$-year old) had lower BMI, higher ferritin levels compared to younger patients with thalassemia. This data are also in agreement with Hershko [15] and Ghone et al., [16] who demonstrated that iron overload in thalassemia patients is the main outcome of multiple blood transfusions which added about $100-200 \mathrm{ml}$ of pure $\mathrm{RBCs} / \mathrm{kg} /$ year (equivalent to $108-216 \mathrm{mg}$ of $\mathrm{Fe} / \mathrm{kg} /$ year) that increased iron stores to many times than the normal range unless regular chelation therapy was given. It also results from increased iron absorption as iron absorption in patients with thalassemia increases several folds than the normal daily intestinal iron absorption which is about 1$1.5 \mathrm{mg} /$ day. Our results are also in agreement with 
Hagag et al., [17] who demonstrated that, significantly higher serum ferritin and iron levels and significantly lower total iron binding capacity were found in thalassemic patients compared with control group.

In our study, there was statistically significant difference between thalassemic patients and control group as regard CRP and ESR which were significantly higher in thalassemic patients especially post splenectomised compared with control group ( $p$-value $>0.05$ ).

This data come in agreement with Ataei and Hashemipour, [18] who found that; thalassemia are classically associated with susceptibility to infections and patients with 3 -thalassemia major who regularly receive transfusions are at risk of developing Post Transfusion Hepatitis (PTH). Among these infections, hepatitis $\mathrm{B}$ and $\mathrm{C}$ are the most common so ESR and CRP were elevated in thalassemia. In another study, Sari and Gatot, [5] reported that; high level of C-reactive protein among beta thalassemia was more pathognomonic in case of splenectomized patients.

In the present study, there was statistically significant difference between thalassemic patients and control group as regard CD4 [T-lymphocyte] and CD8 [T-lymphocyte] which were significantly higher in post splenectomised thalassemic patients compared with non splenectomised thalassemic patients and control group ( $p$-value >0.05).

In the current study, there was no statistically significant difference between thalassemic patients either splenectomised or not as regard CD4/CD8 ratio while there was statistically significant difference between post splenectomised thalassemic patients compared with control group ( $p$-value $<0.05)$.

This data come in agreement with Gharagozloo et al., [19] who showed that, CD4+ and CD8+ T lymphocyte were higher on post-splenectomy groups compared to non-splenectomised thalassemic patients. This is due to Increased T lymphocyte count on post-splenectomy which might be associated with antigen that could not be effectively filtered by spleen. This suggests that spleen could play some part in the regulation of lymphocyte counts and act as a reservoir for lymphocytes produced in the body. Aleem et al., [20] who showed that, iron and its binding proteins have immune modulating properties and the effects of the iron overload include alternations in T-lymphocyte subsets and modification of lymphocyte distribution in different compartments of immune system. Iron overload has been associated with increase of CD8 and decrease in CD4 cell counts but use of iron chelators as deferasirox induced reduction in the iron overload and may has direct effect on immune system that cause increased CD8 cells and higher CD4 cell counts resulting in mildly increased or normal CD4/CD8 ratio.

On the other hand, this data are not in agreement with Sari and Gatot, [5] who showed that patients with thalassemia major has increased amount and activity of suppressor cell CD8+ but decrease ratio of CD4+/CD8+, decrease of T lymphocyte proliferation and increase $\mathrm{T}$ lymphocyte activation.

Also, this data are not in agreement with Hagag et al., [17] who showed significantly lower CD3, $\mathrm{CD} 4$ and $\mathrm{IgM}$ and significantly higher $\mathrm{CD} 8, \mathrm{IgG}$ and $\operatorname{IgA}$ levels were found in thalassemic patients compared with controls. This is because repeated blood transfusions can lead to continuous alloantigenic stimulation with auto-immune hemolysis, $\mathrm{T}$ and $\mathrm{B}$ lymphocyte changes and modification of monocyte and macrophage functions.

In our study, there was statistically significant difference between thalassemic patients and control group as regarding interleukin 10 which was significantly lower in post splenectomised thalassemic patients compared with non splenectomised thalassemic patients and control group ( $p$-value $>0.05$ ).

This data are in agreement with Caligiuri et al., [21] who showed that, IL10 production by splenectomised patients are less than non-splenectomised. This is because multi-transfusions could be responsible for a change in the subset of circulating lymphocytes that could contribute to a state of partial immune deficiency in B-thalassemia patients, which is more prominent among the splenectomised patient. Also Jison et al., [22] showed that, IL-10 is a cytokine with potent anti-inflammatory activity which reduces the production of various cytokines including IL-1, IL-6, IL-8, IL-12, TNF$a$ and GM-CSF to promote uptake and retention of iron in the reticulo endothelial system so patients with iron overload have decrease in interleukin 10 as there is negative correlation between interleukin 10 and serum ferritin which reinforce the existence of a clear inflammatory state in patients with iron overload as a result of excess iron.

The discrepancy between the results in different studies may be due to the difference in the number of sampled patients, frequency of blood transfusion, spelenctomy, serum iron status and iron chelation therapy which were 'proposed as the responsible 
factors for alteration of immunoglobulins and $\mathrm{T}$ lymphocyte subset in patients with thalassemia'.

\section{Conclusion:}

There were significant higher level of CD4, CD8 and lower IL10 in the splenectomised thalassemic patients than non splenectomised thalassemic patients and controls.

Our patients with thalassemia major were susceptible to infection especially after splenectomy and with bad chelation.

\section{Acknowledgments:}

This research was carried out without funding.

\section{Conflicts of interest:}

No conflicts of interest declared.

\section{Authors' contributions:}

All authors had equal role in design, work, statistical analysis and manuscript writing. All authors have approved the final article work.

\section{References}

1- GUMUS P., KAHRAMAN-CENELI S., et al.: Association of thalassemia major and gingival inflammation. Arch. Oral. Biol.; 64: 80-4, 2016.

2- ZAHRAN A.M., ELSAYH K.I., et al.: Regulatory B cell (CD19 (+) CD38 (hi) CD24 (hi)) in alloimmunized and non-alloimmunized children with beta-thalassemia major. Blood Cells Mol. Dis.; 57: 91-6, 2016.

3- TAHER A.T. and CAPPELLINI M.D.: Recent advances and treatment challenges in patients with non-transfusiondependent thalassemia. Blood Reviews; 26S: S 1-2, 2012.

4- LADIS V., CHOULIARAS G., et al.: Longitudinal study of survival and causes of death in patients with thalassemia major in Greece. Ann N Y Acad. Sci.; 1054: 445-50, 2005.

5- SARI T.T. and GATOT D.: Immune response of thalassemia major patients in Indonesia with and without splenectomy. Acta. Medica. Indonesiana.; 46 (3), 2016.

6- SHOUVAL D.S., OUAHED J., et al.: Interleukin 10 receptor signalling: Master regulator of intestinal mucosal homeostasis in mice and humans. Adv. Immunol.; 122: 177-210, 2014

7- SABAT R.: IL-10 family of cytokines. Cytokine Growth Factor. Rev.; 21: 315-24, 2010.
8- YANG X.O. and PANOPOULOS A.D.: STAT3 regulates cytokine-mediated generation of inflammatory helper T cells. Journal of Biological Chemistry, 282 (13): 9358 63, 2007.

9- KIRKPATRICK L.A. and FEENEY B.C.: A Simple Guide to IBM SPSS Statistics for Version 20.0. Student ed. Belmont, Calif.: Wadsworth, Cengage Learning, 2013.

10- ELMEZAYEN A.D., KOTB S.M., et al.: Beta-globin mutation in Egyptian patients with beta-thalassemia. Lab. Med.; 46: 8-13, 2015.

11- CHERN J.P., SU S., et al.: Survival, mortality, and complications in patients with beta-thalassemia major in northern Taiwan. Pediatr Blood Cancer; 48: 550-4, 2007.

12-REKHA V.I.J. and ROBERTO F. MACHADO: Pulmonary Complications of Hemoglobinopathies. Chest; 138 (4): 973-83, 2010

13- MARTIN A. and THOMPSON A.A.: Thalassemias. Pediatr. Clin. North Am.; 60 (6): 1383-91, 2013.

14-EISSA D. and EL-GAMAL R.: Iron overload in transfusion dependent beta thalassemia patients: Defining parameters of comorbidities. The Egyptian Journal of Haematology; 39: 164-70, 2014

15- HERSHKO C.: Pathogenesis and management of iron toxicity in thalassemia. Ann. NY Acad. Sci., 1202: 1-9, 2010.

16- GHONE R.A. and KUMBAR K.M.: Oxidative stress and disturbance in antioxidant balance in beta thalassemia major. Indian J. Clin. Biochem., 23 (4): 337-40, 2008.

17- HAGAG A., ELGAMASY M., et al.: Immune status in children with Beta Thalassemia in Correlation with Iron Overload: Journal of Endocrine, Metabolic \& Immune Disorders-Drug Targets; 16: 1-8, 2016.

18- ATAEI B., HASHEMIPOUR M., et al.: Prevalence of anti HCV infection in patients with Beta-thalassemia in Isfahan-Iran. Int. J. Prev. Med.; 3: S118-23, 2012.

19- GHARAGOZLOO M. and KARIMI M.: Double faced cell-mediated immunity in 3 -thalassemia major: stimulated phenotype versus suppressed activity. Ann. Hematol.; 88: 21-7, 2009.

20- ALEEM A., SHAKOOR Z., et al.: Immunological Evaluation Of 3 -Thalassemia Major Patients Receiving Oral Chelator Deferasirox: Journal of the college of physicians and surgeons Pakistan; 24 (7): 467-71, 2014.

21- CALIGIURI G. and KAVERI S.: When interleukin-18 conducts, the preludio sounds the same no matter who plays. Arterioscler. Thromb. Vasc. Boil.; 25: 655-7, 2005.

22- JISON M.L., MUNSON P.J., et al.: Blood mononuclear cell gene expression profiles characterize the oxidant, hemolytic, and inflammatory stress of sickle cell disease. Blood; 104 (1): 270-80, 2004. 


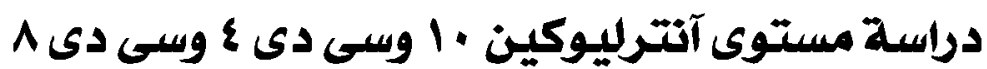

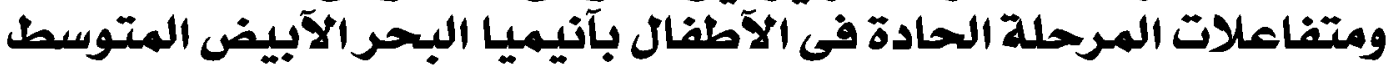 مع تآثير إستئصال الأمال بأيميال}

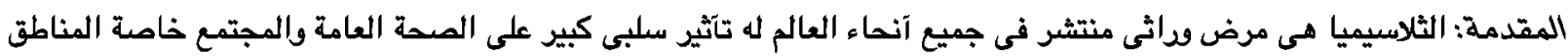

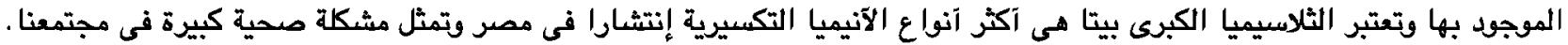

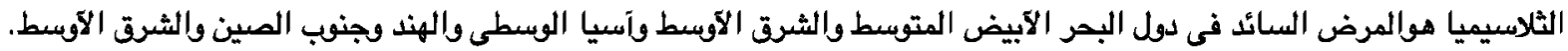
الهدف من البحث: الهدف من هذا العمل دراسة مستوى (آتترليوكين . ال وسىى دى ع وسىى دى ^) فى الآطفال المصابين بآنيميا البحر الآبيض المتوسط وعلاقتها بمتفاعلات المرحلة الحادة وتآثير إستئصال الطحال.

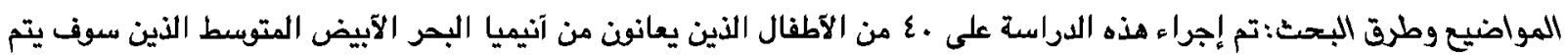

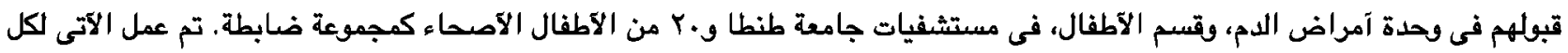

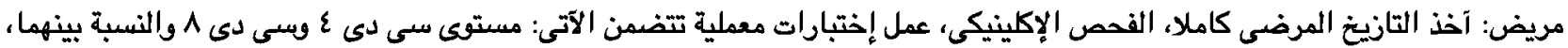

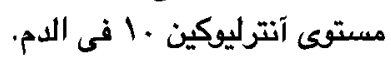

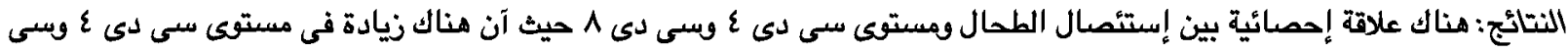

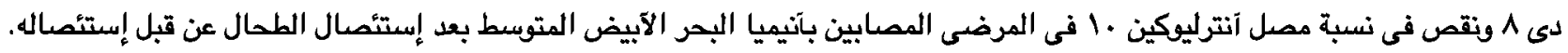

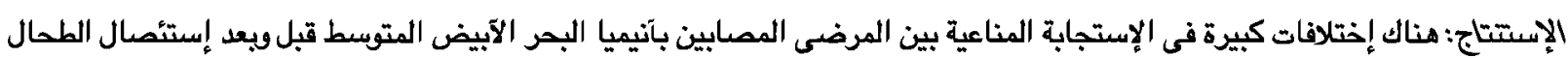

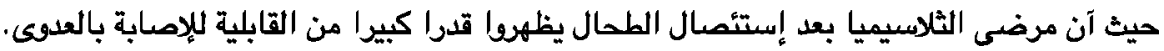

